\title{
Vietnamese higher education and the issue of enhancing graduate employability
}

\author{
June (Thi Tuyet) Tran, La Trobe University/ Vietnam National University, Hanoi \\ j.tran@latrobe.edu.au/ tuyettt@vnu.edu.vn
}

\begin{abstract}
The rapid change in the graduate labour market in the globalizing era calls for responsiveness from the higher education systems all over the world. Enhancing graduate employability has become a topic of both concern and debate in higher education worldwide. However, the issue is somehow different in Western developed countries and in Eastern developing countries in terms of the way higher education teaching staff perceive the issues, the way universities approach the issues and also the way university practices have been designed to enhance graduate employability. This article aims to illustrate the differences by addressing the issue of enhancing graduate employability in Vietnam compared with that in the literature from developed countries such as the United States of America (USA), the United Kingdom (UK), Australia and New Zealand. It is suggested that while not all academics in Western higher education systems support the idea of accepting enhancing graduate employability as one of the university missions, their teaching practices, in general, support the development of graduate generic attributes, which are claimed to be essential and necessary for graduates to enter the labour market, to succeed at work and in life. By contrast, in the Vietnamese higher education system, where the main mission for universities is still limited to producing an educated labour force for industry, however, the traditional teaching and learning method and the lack of connections between university, research institutions and the internal industry all hinder the effort of the whole system in preparing students with the necessary skills and knowledge required by the contemporary labour market.
\end{abstract}

Keywords: higher education, graduate employability, Vietnam, Western countries.

\section{Introduction}

Over the last two decades organisations have been increasingly influenced by the effects of globalisation. Under the globalised economic competitive pressures, organisations in both developed and developing worlds have undergone massive restructuring through downsizing and delayering leading to job insecurity and emerging new career patterns (Clarke, 2007). In the UK, USA, Australia, as well as in other developed countries in Europe, employability remains high on the agenda for higher education institutions (HEls), and students in these countries become more selective in their choice of courses and institutions (Rae, 2007). In developing countries such as in Vietnam, the issue has recently emerged as HEls respond to the requirements from the internal economy, and as the number of unemployed or underemployed graduates has become alarming (Pham, 2008; Tran, 2010b; Tran \& Swierczek, 2009).

In Western countries ${ }^{1}$, employability remains a complex and contentious issue without "a clear or obvious solution" (Rae, 2007, p. 605) in HEls. Enhancing graduate employability seems to remain a challenge to higher education (HE) culture and curriculum, and has not yet gained the support of most HE academics (Harvey, 2000; Yorke, 2006). Many graduate employability enhancing agendas

\footnotetext{
${ }^{1}$ In this article the concept of 'Western countries' is relational. It refers to North America and Europe, generally considered the centre of social theory that informs higher education (Connell, 2007).
} 
have been introduced in HE with initiatives such as sandwich programs, work placements, cooperative programs, practicum placements, internships, career advice, mentoring and extra-curricular experiences. However, as suggested by Rae (2007), it is quite likely that in the minds of students these activities are "unconnected" (p. 608). In addition, as the production of academic knowledge "tends to privilege theory and conceptual knowledge over practical application" (pp. 608-609), the introverted nature of academic organisations does not seem to support the change. Many academics still see the adoption of an employability agenda as irrelevant to the university mission (Bates, 1999; Billett, 2009; Harvey, 2000; Morley, 2001; Rae, 2004).

Nonetheless, under the requirement and pressure of governments, industries and the competition that universities face in recruiting students, there has been more and more evidence of the cooperation between HEls and enterprises with the aim to shorten the 'learning curves' of graduates when they start employment after graduation (Mason, William, \& Cranmer, 2009). Most importantly, the nature of teaching and learning practices in developed countries is generally supportive of the purpose of developing students to be effective learners and subsequently, effective workers, with interactive and personal attributes such as communication, teamwork and interpersonal skills high on the agenda (Harvey, 2000, 2005).

In Vietnam, the situation is somewhat different. Though Vietnam has implemented the economy liberalisation policy (known as Doi Moi policy) for more than 20 years and its economy has changed to a market economy with a socialist orientation, the development of both its economy and higher education system (HES) is at a much lower stage (George, 2010). Though 'work-readiness' is of much concern to most related stakeholders including employers, HEls, students and their families, not much has been done for the connection between HEls and enterprises in the country. Universities, with the prime mission of 'training' rather than 'education', seem to accept career orientation as one of its missions (Pham, 2008; Tran, 2006). However, the traditional teaching and learning methods in HEls, the inadequate infrastructure, the lack of funding and the lack of connection among university, research institutions and the internal industry all hinder the effort in preparing students with necessary skills and knowledge required by the contemporary labour market (Dapice, D., Perkins, D., Nguyen X. T., Vu T.T. A., Huynh T. D., Pincus, J., \& Saich, T., 2008). One of the desirable student outcomes of all HEls in Vietnam is to meet the demand of the profession on work-readiness (Harman \& Nguyen, 2010), but not much evidence has been found in the actual strategies employed by different institutions to enhance graduate employability (Tran, 2010b).

\section{Enhancing graduate employability in the Western literature}

From the end of the twentieth century, graduate career and employment patterns have changed significantly. In an increasingly global competitive market, with the development of information technology and the mobilisation of workers across boundaries, organisations and enterprises have undergone massive restructuring of downsizing, de-layering and out-sourcing (Cascio, 1993; The Association of Graduate Recruiters, 2009). There is limited job security for workers. Job-for-life contracts in the traditional manner have been replaced by short term contracts (Capelli, 1999). Perspectives on careers have also changed accordingly. When many traditional jobs which were characterised by long-term, stability and security offers and mutual trust have disappeared, the new career patterns are more likely to be characterised by "flexible employment contracts, multi employers, lateral job moves and multi career changes" (Clarke, 2008, p. 8). As a result, linear careers seem to be replaced by more flexible, adaptive career patterns such as protean careers (Hall, 1996; Mirvis \& Hall, 1996), boundary-less careers (Arthur, 1996), portfolio careers (Cohen \& Mallon, 1999; Handy, 1994), intelligent careers (DeFillippi \& Arthur, 1994) and post-corporate careers (Peiperl \& Baruch, 1997). The changes reflect the new characteristics of the labour market and also the desire of many graduates, who now may prefer independence to employment security (Clarke \& Patrickson, 2008). Career management is no longer managed by organisations, instead it becomes "a process through which an individual makes a contract with him/herself to make sense of experiences, manage career choices and seek personal fulfilment" (Hind, 2005, p. 269). In other words, each individual has to be in charge of their own career management and job security which is anchored in their own "portable skills and employability" (Mallon, 1998, p. 363). 
Definitions of employability vary, but in general, it refers to an individual's relative ability and potential to obtain, to retain and to move between suitable jobs within the current labour market context. For example Hilar and Pollar (1998) define employability as "the capacity to gain initial employment, maintain employment and obtain employment if required" (p. 2). Sanders and De Grip (2004) refer to it as "the capability and the willingness to be and to maintain attractiveness in the labour market, by anticipating changes in tasks and work environment and reacting to these changes in a proactive way" (p. 76). In a more recent definition of employability, Knight and Yorke (2004) add a new element of 'satisfaction' that "employability is having a set of skills, knowledge, understanding and personal attributes that make a person more likely to choose and secure occupations in which they can be satisfied and successful" (p. 280).

Employability in higher education contexts often refers to the ability of graduates to find and retain a graduate-level job and also the ability to move between jobs if required. The question is what a graduate-level job is like? Smith, Knight and Naylor (2000) suggest that graduate jobs include both 'traditional graduate occupations (such as doctors, teachers and lawyers) and graduate jobs that require a high level of education, that require and also are often filled by graduates, and that offer entry routes to higher level positions. There is also a 'track' of non-graduate jobs, which are claimed not to require and not to make use of graduate-level skills and knowledge (Elias \& Purcell, 2004; McKnight, 1999; Pool \& Sewell, 2007). Some examples of non-graduate occupations are clerical, personal service, sales, skilled trade and labouring (Elias \& Purcell, 2004).

In general, most definitions of employability suggest that "individual characteristics and behaviours determine employability" (Clarke, 2007, p. 262). However, there is also a suggestion that graduate employability is highly dependent on the context of the current labour market (Clarke, 2007) as well as on personal circumstances and capacity for job flexibility and mobility (McQuaid, 2006). Thus, there is a link between employability and employment: where employability is understood as suitability for graduate employment, it may increase graduates' chance to get graduate-level jobs, but does not assure them (Clarke, 2007; Knight \& Yorke, 2004; Yorke, 2006).

Different frameworks or components of graduate employability have been developed for the interpretation of employability of university graduates (See, for example Bennett, Dunne, \& Carre', 1999; Hillage \& Pollard, 1998; Yorke \& Knight, 2004). Overall there are four stakeholders involved in the framework for graduate employability including universities, governments, employers and the graduate themselves, and the interest in graduate employability has "arguably produced benefits for all stakeholders" (Crossman \& Clarke, 2009, p. 602). For employers, employability often refers to 'work-readiness', meaning that the transition from university to work, or the learning curve from HE to employment will be shortened as a result of graduate employability enhancing agenda in HE (Mason, et al., 2009). From employer as well as government perspectives, employability is mainly concerned with the capability of graduates to contribute to the economic competitiveness in a global context soon after their commencing employment (Cranmer, 2006). A graduate employability focus also benefits students, who increasingly recognise that having a university degree is simply not sufficient, and they require other attributes to be employable (Rae, 2007). Thus, finding jobs and becoming employable is one of the important considerations in their choice of course and institution. Universities response by including employability in their agenda, which includes modification to existing course curricula, provision of new courses and teaching methods and opportunities for work experience - all intended to make more explicit the acquisition and the development of employability within the higher education context. This increases the responsiveness of higher education to add more value for their credentials (Tomlinson, 2008) and increases the competitiveness of the institution in the increasingly challenging higher education market.

Nonetheless, enhancing graduate employability is a complex process and it involves three levels of communication: between institutions and businesses, between institutions and students, and between businesses and students (Bhanugopan \& Fish, 2009). In an ideal model, an employer gets involved in course design and delivery by providing comments on the relevance of the course content, providing work placement and material for students and giving guest lectures. In such cooperation, employers' information about job applicants is likely to be improved (Mason, et al., 
2009), universities also have an opportunity to reflect on their courses and curricula, and students become familiar with the requirements of the employment market.

In practice, this kind of model is not so popular, and there has been much evidence of the mismatch or the gaps between these three levels of communication (Bhanugopan \& Fish, 2009). Many academic staff are suspicious about the idea that university could or should contribute to graduate employability as the prevailing culture of academic organisations is "often to focus onwards, on the organisation of academic structures and on the subject discipline of research and course curricula" (Rae, 2007, p. 608). The production of academic knowledge, in Western developed countries in general, tends to privilege theory and conceptual knowledge, rather than practical application, and thus, the adoption of an agenda of employability, which is considered to meet the practical needs of industry, may also mean 'irrelevant' (Rae, 2004). Employers, on the other hand, often value practical skills, enterprise skills and business awareness, which are often the outcome of enterprise involving and learning (Mason, et al., 2009). Students often do not see the importance and the connection between university provided programs and services such as project-based learning, work-related learning, career advice and extra-curriculum activities and the propensity of getting graduate job after graduation (Rae, 2007). Thus they do not make full use of the support of the university for the transition to work.

Nonetheless, graduate employability is not only a product of the learning at university, but it is the outcome of:

the cumulative learning over a series of course modules, together with parallel personal development through a range of formative experiences and wider contextual learning through, for example, work experience and extra-curricular activities; It is a product of the whole university experience combined with interactions with the wider "world of work". (Rae, 2007, p. 608).

Obviously the primary responsibility for employability rests with individual students and graduates (McQuaid \& Lindsay, 2005; Van Buren III, 2003). In Western higher education, students are supposed to take high responsibility for their study, they are often the ones who decide what course/subject they want to learn, what extra-activities they want to join in. They are also considered as the centre in their learning, thus, in many cases, teachers are mainly facilitators (O'Dwyer, 2006; Phan, 2008). Then, when they finish university and start searching for jobs in the labour market, the onus is also on them as potential employees to "acquire knowledge, skills and abilities, and other characteristics valued by current and prospective employers" (Fugate, Kinicki, \& Ashforth, 2004, p. 15). In order to be employable, students and graduates are the ones who need to be active in their learning. They also have to actively widen their knowledge, improve their skills and understanding, and shorten the learning curve when they start employment.

Nonetheless, universities and employers also play an important role in shaping and developing employability for graduates. There is a gap between what universities offer and what is required by the labour market (Holland, 2006). Students are the ones who need to handle the difficulties brought with the gap to be successful at employment. However, if both universities and employers are willing to work together to bridge the gap, the 'job-readiness' and employability of graduates will be strengthened by the support and the cooperation between the two (Chapple \& Tolley, 2000; Fallows \& Steven, 2000; Harvey, 2005). For example Junghagen (2005) suggests:

It is an important role of a business school. . .to not only follow trends and developments in industry but also to function as an actor taking part in driving and stimulating this development. At the same time, continuous input from industry is essential to define future practice. (p. 73)

Employability has become a publicly reportable statistic, and many universities see employability as an institutional achievement, having developed employability strategies and associated provisions (Rae, 2007). Degree programs in many universities in the West now tend to focus on the acquisition of two types of skills, subject specific knowledge and skills and transferable knowledge, skills and

Tran, T.T. (2012). Vietnamese higher education and the issue of enhancing graduate employability. Journal of Teaching and Learning for Graduate Employability, 3(1), 2 - 16 
attitudes (Cox \& King, 2006). Universities have started to acknowledge the need for graduates to "develop a range of personal and intellectual skills beyond specific expertise in an academic discipline" (Shah, Pell, \& Brooks, 2004, p. 9). However, debate continues about the extent to which this is achieved at a practical level (Crossman \& Clarke, 2009). There is resistance and suspicion from academic staff, though not often articulated in print, that the employability agenda will downgrade education to training, erode academic freedom, infringe academic autonomy, undermine critic and result in 'training' rather than 'education' in HE (Bates, 1999; Billett, 2009; Harvey, 2000; Morley, 2001). Such questions as "do universities exist simply to meet the needs of modern capitalism and are students being constructed solely as future worker, rather than fully rounded citizens?" (Morley, 2001, p. 132) or "should HE be about training graduates for jobs rather than improving their minds" (Harvey, 2000, p. 3) seem to be common among HE academic staff.

The academic's fear, as suggested by Knight and Yorke (2004, p. 34) is probably legitimate where employability is understood as the intrusion of skills agenda into the curriculum, and as it may bring more work for academic staff. They may also not be enthusiastic with the interference of employers, the outside stakeholders (Knight \& Yorke, 2004; Yorke, 2006). However, closer analysis of what employers are looking for when employing graduates reveals "congruity between the abilities developed in HE and those desired by employers" (Harvey, 2005, p. 23). Harvey also explains that although emphasis both within and between organisations varies, at root, employers want interactive and personal attributes. Communication, teamwork and interpersonal skills are the core interactive attributes. Personal attributes consist of attitudes and ability including intellect, knowledge, willingness and ability to learn and continue learning. All of these attributes are desirable in HE. The teaching practices at HE level in Western countries also aim to develop these attributes for students. Students are educated to be autonomous learners, to build up strong communicative and interpersonal skills, to handle teamwork assignments effectively, to know how-to-learn and to become intellectual and knowledgeable in their study field. With the current teaching practices in Western universities, graduates could develop attributes which are desirable by employers in the labour market. The questions rest on to what extent universities should help students acquire enterprise skills by providing work-related practices during university time, which is traditionally a responsibility of the industry. Or in other words, to what extent universities should help graduates shorten the transition from university to work and satisfy employers, who, in a highly competitive market, no longer want to offer training for their new employees.

\section{Higher education in Vietnam: training for specific professions rather than education}

It seems clear that in Western countries, higher education should be characterised by the focus on education, whereas training for specific skills is the main mission of the professional schools or TAFE colleges. In contrast, education in Vietnam, as suggested by Ta and Winter (2010, p. 155), refers to primary and secondary education, while training refers to higher education. The name of the central Ministry, the Ministry of Education and Training (MOET) also reflects this order (Ta \& Winter, 2010). The main mission of university is still limited to produce an educated labour force for the industry (Tran , 2006). Education law also reinforces the mission of the HES: "university education shall help students acquire in-depth professional knowledge and fluently practical skills in one profession with the ability to work independently and creatively as well as to solve problems in the field of study" (The Education Law, 2005, p. 16). It emphasises the responsibility of $\mathrm{HE}$ to provide professional knowledge and skills, to satisfy the demands of the labour market, and the need to modernise and industrialise the country (Pham, 2008, p. 149). Recently the Vietnamese government has implemented different strategies to encourage academic staff in the HES to engage in research; however, the research capacity of universities has remained very low; the majority of academic staff still consider the traditional mandate of university as the production of human resources rather than engagement in research (Tran, 2006, p. 5). Research is a typical mission of research institutions which are separated from universities (Harman \& Nguyen, 2010; Hayden \& Lam, 2010). Up until recently, the main contribution of the HES in Vietnam has been providing labour force, first for domestic enterprises and then for foreign direct investment (FDI) enterprises. 
The structure of HE has been also "fundamentally designed to meet the needs of the labour market" (George, 2010, p. 34). Since the time Vietnam gained independence, the system was built following the old Soviet system, where all HEls were small, mono-disciplinary, or in other words, very specialised to train the labour force to meet the projected labour requirements of each sector (George, 2010). Originally, many universities were formed by and under their line ministries. For example the University of Health was placed under the Ministry of Health, the University of Agriculture was under the Ministry of Agriculture and Development. Up until recently, 13 major universities have remained under their Line Ministries as well as MOET.

In Vietnam, education in general and higher education in particular has been considered as an investment, rather than a tool for liberation and empowerment as such in the West (Nguyen, Terlouw, \& Pilot, 2005). From the government perspective, investment in education and training "must be regarded as one of the main targets for development investment" (MOET, 1995, p. 14). Pham Minh Hac the former Vice-Minister for Education, also states this aim very clearly:

Investment in education is investment in development, being the fundamental investment in the socio-economic strategy. Subsequently, especially as from 1991 and since the fourth Plenum of the party Central Committee (1993) the view has become clearer and education is regarded as part of the socio-economic infrastructure. (Pham, 1998, p. 29)

From the perspective of the student's family, the investment for students to study in higher education is considered an investment for their future with a good and high income career (Tran, 2010c). Thus, a career in higher education is considered very important, and intellectuals are usually thought to possess an elevated career (Pham \& Fry, 2004). Evidence also shows that Vietnam HES also places high value on career orientation and development. One of the criteria for the system to evaluate the quality of students in different institutions is to ascertain a student's ability to find jobs after graduation (Pham \& Fry, 2004, p. 211).

The comparison between the view of the Western academics and the Vietnamese academics on the issue of enhancing the employment capability of students and graduates reveals some interesting contradictions. The employability agenda is considered by many academic staff in the West as irrelevant, as the main mission of $\mathrm{HE}$ is to promote research, to improve students' minds, and HE is about education, not about training for jobs (Bates, 1999; Billett, 2009; Harvey, 2000; Morley, 2001). Conversely, in Vietnam, there seems to be too much focus on the training for jobs, and neglecting other missions. Hence, it is easy to find such argument as:

Universities are responsible for more than simply training highly qualified specialists for socio-economic development. They also have an important role to play as vanguard in intellectual exploration, the generation of knowledge and the inculcation of democratic values (Pham, 2010, p. 56).

Obviously, the training knowledge and skills for specific jobs has remained one of the most important missions of HES in Vietnam.

\section{The mismatch}

Although the mission of training university students for the labour market and for socio-economic development of the country is considered an important mission of the HES in Vietnam, it does not seem to be implemented successfully. The gap between higher education and the industry has become wider and wider since the implementation of the economic liberalization policy. Though the graduates required by the industry outnumber the supply from HES, many graduates have experienced difficulties in finding jobs, many end up unemployed or underemployed, when employers still complain about the lack of graduates with appropriate knowledge and skills (Pham, 2008; Tran, $2010 \mathrm{~b})$. The mismatch reflects the stagnation of the HES compared to the development of the internal economy. It also reflects the weak linkage between the two. 
With the economic liberalisation in 1986, the Vietnamese government aimed to change Vietnam from a central planned economy to a market-oriented one. The economy turned to be a transitional economy with many new sectors, such as private sector, cooperate sector, joint-venture and FDI enterprises instead of only state and co-operate sectors in the central planned economy (Nguyen , 2006; Pham \& Fry, 2004). In terms of HE, the government abolished job allocation for graduates, who now have both the right and the responsibility to find jobs for themselves. School fees have been introduced in the system. In addition to only state HEls in the past, many new private and foreign HEls have gradually established. The system has expanded significantly, the number of students enrolling in the system has increased more than 16 times in 2010 compared to 1987 (from about 130 thousand to more than 2.1 million students) (General Statistics Office of Vietnam, 2012). HES in Vietnam has changed from elite to mass HE (Tran, 2010a).

HES has been struggling under pressure to develop the system to meet the new needs of the economy. Universities face too many challenges in the transitional period. First, they lack teaching staff, the number of students has increased 16 times, whereas the number of teaching staff has increased only slightly more than three times in the same period (General Statistics Office of Vietnam, 2012). Second, they lack funding and resources as state universities rely mainly on state budgets and school fees for private universities are also under state government control (Evans \& Rorris, 2010). However, the biggest challenge of the system is to renovate an education system which inherits outdated infrastructure and outdated teaching methods.

The traditional teaching in universities in Vietnam was to provide workers for a command economy, where workers were required to follow orders, to listen and obey, rather than being creative and taking initiative. Thus, the teaching at HE was, and currently strongly reflects both Confucian culture and the old Soviet system top-down approach, where the teacher is considered the primary source of knowledge. The main duty of students has been receiving knowledge from the teacher and then relearning it for the exam. Hence, in the international literature, Vietnamese students are often considered as passive learners (Flowerdew \& Miller, 1995; Nguyen, 2002; Stephen, Doughty, Gray, Hopcroft, \& Silvera, 2006; Thompson, 2009; Tran, 2012).

However, after the economic liberalisation, with the massive development of both private and FDI sectors which offer much higher wages for their staff, the traditional products of the Vietnam HES, the passive learners and workers, do not appear to be suitable to work in these sectors. Especially when Vietnam has integrated more and more into the global market with its becoming a member of Association of Southeast Asian Nations (ASEAN) in 1995 and the World Trade Organisation (WTO) in 2007, the internal economy also needs to change to respond to the international competitive market. Instead of requiring loyalty, hard-work and obedience as in the central planned economy, employers now require graduates to understand a foreign language, especially English, to have good communication skills, teamwork and personal skills and obtain such characteristics as initiative and being proactive (Tran, 2006; Tran \& Swierczek, 2009). The Vietnamese education system in general and the HES in particular are facing the most significant challenge: changing the teaching philosophy and practices to enhance graduate employability skills the contemporary industry requires.

\section{The effort for the change}

Recognising the weakness of the HES and the mismatch between the HES and the industry, the Vietnamese government has made a great effort to renovate the system. In 2005, an ambitious comprehensive reform of higher education aimed to have a highly competitive, international standard higher education system by 2020. This reform, named "Fundamental and Comprehensive Reform of Higher Education in Vietnam 2006-2020" (also known as Higher Education Reform Agenda, or HERA), was proclaimed by the Vietnamese government (Harman \& Nguyen, 2010). Some of the major objectives stated in the HERA were to develop a curriculum that has a strong applied/professional orientation with the shift from the instructional to the learning paradigm, with special pedagogical consideration in order to meet the demand for more relevant graduate skills for the economy (Harman \& Nguyen, 2010; Pham Thanh Nghi, 2010). With the HERA, it is recognised that: 


\begin{abstract}
There has been a particular demand for 'industry ready' graduates with a broader range of high-level and adaptable skills. Skills of particular relevance needed are critical thinking, initiative and enterprise, information literacy, planning and management skills, capacity for lifelong learning, and flexibility in preparing for jobs yet to be envisaged and for adapting to multi-disciplinary contexts. Developing foreign language and business skills are also seen to be critical in countries like Vietnam in transition to a new order (Harman \& Nguyen, 2010, pp. 72-73).
\end{abstract}

An agenda which maintains a strong focus on job orientation is also an objective of HERA. HERA aims to develop a system of $80 \%$ of students enrolling in professional oriented programs, and only $20 \%$ of students enrolling in research oriented programs by 2020 . The Vietnamese government has also recognised that the workplace that graduates enter now is vastly different from that of a decade ago. There has been a growing need for graduates with relevant skills to be 'industry-ready' (Harman \& Nguyen, 2010, p. 72), or in other words, to be employable with a broader range of high-level and adaptable skills.

The traditional instructional paradigm with the passive transmission of information in the lecture format is no longer appropriate especially for the aim of educating initiative and proactive future workers. In order to assist graduates to be capable in the workplace after graduation, universities now are 'encouraged increasingly by external constituencies to strengthen both undergraduate and postgraduate education, with greater emphasis on the quality of learning experience' ( $p$ 68). Lecturers in HEls are being urged to move from passive to interactive teaching modes. They are also encouraged to change from the traditional teacher-centred teaching method to employ studentcentred teaching and learning and problem based learning with new principles promoted by MOET: 'teaching how to learn' and 'learning how to learn' (Nguyen, 2005, p. 18). Academic staff have recently been required to know how to support and advise students, how to facilitate learning through applying a range of innovative learning processes and be capable of linking learning with life experiences and service in the community (Harman \& Nguyen, 2010).

\title{
The hurdles to the change
}

With HERA, the Vietnamese government has made a strong effort to reform the HES with one of the ambitious objectives of bringing HES and the industry together. However, what is not clear from HERA are the actual steps to implement this goal. In practice, HERA faces enormous challenges. The major hurdles discussed here are the lack of resources to implement the goal, the centralised governance in the system, the rigid curriculum, teaching staff limitations and the weak linkage between HEls and the industry.

All reform needs time and investment. As it is not stated in the HERA, universities are suspicious over the funding resources to implement the HERA goals at institutional level, whereas universities are still struggling to seek funding to maintain its current practices (Hayden \& Lam, 2012). University infrastructure and facilities are both old and outdated and are still waiting for funding to upgrade and to change. The modernisation of facilities in the HES may take long as the investment in HE is very low. The Deputy Prime Minister and former Minister of Education Nguyen Thien Nhan reported at the Regional HE Conference in Kuala Lumpur in December 2007 that the expenditure on HE in Vietnam was increased but still low, was only US $\$ 400$ per student per year (Nguyen, 2007, p. 16). He also indicated that though the public expenditure on education had increased from $4.2 \%$ of Gross Domestic Product (GDP) in 2000 to $7.5 \%$ in 2006, only 15\% of which was for HE, the majority education expenditure (71\%) was for kindergarten and general education ( $p .16)$. It is observed by many academics that the rate of expenditure on HES in Vietnam is too low, not sufficient and has lagged behind the rates for most HESs in the region (Hayden \& Lam , 2010). It seems clear that Vietnam does not have sufficient financial resources to implement HERA (Smith \& Nguyen, 2010).

Universities not only do not have sufficient funding to implement HERA's goal, they also do not have much accountability to respond to the need of the labour market, as Pham Thanh Nghi suggests "the efficacy of higher education has been hampered by the resilience of an outmoded and extremely 
conservative management mechanism, known as "centralisation"' (2010, p. 55). Up until recently, most important decisions in each institution, both public and private, are still made by the central ministry, MOET (Hayden \& Lam, 2010; Pham, 2010). More profoundly, the rigid and outdated curriculum all institutions have to adapt to is under the control of MOET. The Ministry wants the communist ideology to remain in the 'socialist' education system, where there is a strong emphasis on 'Marxist-Leninist' and Ho Chi Minh Thoughts in the HE curriculum (Harman, Hayden \& Pham, 2010). When Vietnam opens its door to a market driven economy, but at the same time still keeps the desire to promote Marxist - Leninism, there is a need to address the contradiction between the socialist and capitalist market principles as two contrasting philosophies driving the education system:

Vietnam is probably the only country in the world that both embraces market economics and adheres to Marxism - Leninism. How can an education system, guided by two contradictory philosophies develop in a consistent manner? (Tran, 1999, p. 21).

The Marxism-Leninism also appears to contrast with the subject of the HERA to training university graduates for the needs of a market driven economy. The need for change is long overdue (Pham, 2010). However, despite the claim of how irrelevant the Marxist - Leninist study is, "the line drawn in the sand" has been to reject questions about its importance (George, 2010, p. 45).

The heavy curriculum is also claimed to overload teaching staff in the HES, who are often described as overworked and underpaid, often lacking pedagogical understanding and having low qualifications (Dapice et al., 2008; Hoang, 2009; Tran \& Swierczek, 2009; Vu, 2009; Vu, Dang, \& Tran, 2007; Vu, 2008). When the student-teacher ratio is too high (30:1), when the teachers are overworked, it is hard to require a teaching renovation from them. In addition, most of the teachers in the system were trained in the traditional HES in Vietnam in the past, where they have experienced only traditional teaching and learning methods (Tran \& White, 2012). They themselves may not know what student centred learning really is. It is not a surprise when the student centred learning has been, in theory, deeply embedded pedagogical principle in academia, the teaching and learning in the system is still considered, until recently, outdated with passive learning style of the students (Nguyen, 2002; Stephen, et al., 2006; Thompson, 2009). Graduates who finish four to six years at university are still criticised by many employers as lacking such essential skills for work as communication, planning, teamwork and interpersonal skills (Tran, 2006; Tran \& Swierczek, 2009). Many of them have to take extra courses in soft skills or English with the hope for satisfying employers' needs. HE training is probably still far from the HERA objective of enhancing graduate 'work readiness'.

Nonetheless, graduate 'work-readiness' is not only the responsibility of the HES, it also depends on the level of development of the economy and the cooperation between the HES and enterprises. The Vietnamese market economy is still very young (since the economic liberalisation in 1986) (Fatseas, 2010), with more than $95 \%$ of enterprises being small and medium enterprises (SMEs) (General Statistics Office, 2008). Again, Vietnam is still on the path of a market economy, but with a socialist orientation (George, 2010). The government has not let go of their total control over the internal economy. Many obstacles and disincentives prevent or discourage firms, especially SMEs from developing innovation capability. Firms do not have sufficient resources for long term investment (Tran, 2006). There is also little evidence of effective linkages between firms (including foreign companies) and Vietnamese universities to train human resources or to conduct research together (Fatseas, 2010). Problems include the lack of capability for both firms and universities to negotiate with each other, for learning, researching and sharing information and absorbing new knowledge (Fatseas, 2010). The lack of dynamism in the labour market is another hurdle (Pham , 2010). Then, there is also not enough 'pull' for university academic staff to devote themselves to innovation and to serve industry needs (Tran, 2006). The loose relationship between HES and the industry pushes students and graduates to grope about to find their way entering the labour market. 


\section{Conclusion}

Enhancing graduate employability has obviously become a topic of both concern and debate in higher education worldwide. However, in Western countries such as the USA, UK, Australia and New Zealand, where employability remains a complex and contentious issue with many academics having negative viewpoint on the adoption of employability agenda into HE curriculum, the general teaching practices and the facility and infrastructure of developed countries do support students in developing interactive and personal attributes necessary for them at work and in life. However, in Vietnam, providing a highly skilled labour force for industry is one of the important missions of HEls, the traditional teaching method and the poor and outdated facilities and infrastructure of a developing country prevent HEls in Vietnam from catching up with the demand of the contemporary labour market.

It does not seem to be an easy task for the HES in Vietnam to train students to satisfy the labour market's requirements, to enhance graduate employability and to provide a qualified, highly skilled labour force for the modernization and industrialization of the country. If the related problems such as finance, governance, teaching staff training and limitations and the loose relationship between teaching, research and practice are not soon recognised and settled, it will be hard for the HES to keep up with the changes in the labour market. The ambitious HERA has been considered more as a wish list, rather than a practical plan with clear strategies to implement and practical solutions to reach different objectives (Smith \& Nguyen, 2010). Enhancing graduate employability is not only considered by academic staff and related stakeholders as an important mission of the HES, it has also become a desire of the whole HES and the government in the transitional period. It, however, does not seem to be an easy task for Vietnam with such low investment and ambiguous policies. 


\section{References}

Arthur, M. \& Rousseau, D. (1996). The boundaryless career: A new employment principle for a new organizational era. New York: Oxford University Press.

Bates, I. (1999). The competence and outcomes movement: The landscape of research. In F. Flude \& S. Sieminski (Eds.), Education, training and the future of work II (pp. 99-123). London: Routledge in association with the Open University.

Bennett, N., Dunne, E., \& Carre', C. (1999). Patterns of core and generic skill provision in higher education. Higher Education, 37 (1), 71-93.

Bhanugopan, R., \& Fish, A. (2009). Achieving graduate employability through consensus in the South Pacific island nation. Education and Training, 51(2), 108-123.

Billett, S. (2009). Realising the Educational Worth of Integrating Work Experiences in Higher Education. Studies in Higher Education, 34(7), 827-843.

Capelli, P. (1999). The new deal at work. Boston: Harvard Business School Press.

Cascio, W. F. (1993). Downsizing: what do we know, what have we learned? Academy of Management Executive, 7(1), 95-104.

Chapple, M., \& Tolley, H. (2000). Embedding key skills in a traditional university. In S. Fallows \& C. Steven (Eds.), Integrating key skills in higher education. London: Kogan Page Limited.

Clarke, M. (2007). Understanding and managing employability in changing career contexts. Journal of European Industrial, 32(4), 258-284.

Clarke, M. (2008). Plodders, pragmatists, visionaries and opportunists: career patterns and employability. Career development International, 14(1), 8-28.

Clarke, M. , \& Patrickson, M. (2008). The new covenant of employability. Employee Relations, 30(2), 121-141.

Cohen, L., \& Mallon, M. (1999). The transition from organisational employment to portfolio working: perceptions of 'boundarylessness'. Work, Employment and Society, 13(2), 329-352.

Connell, R. (2007). Southern theory: the global dynamics of knowledge in social science. Crows Nest, NSW: Southwood Press.

Cox, S., \& King, D. (2006). Skill Sets: An approach to embed employability in course design. Education and Training, 48(4), 262-274.

Cranmer, S. (2006). Enhancing graduate employability: Best intentions and mixed outcomes. Studies in Higher Education, $31(2), 169$ - 184.

Crossman, J. E., \& Clarke, M. (2009). International experience and graduate employability: stakeholder perceptions on the connect. Higher Education, 59 (5), 599-613.

Dapice, D., Perkins, D., Nguyen X. T., Vu T.T. A., Huynh T. D., Pincus, J., \& Saich, T. (2008). Choosing success: The lessons of East and Southeast Asia and Vietnam's future. Cambridge: Harvard University.

DeFillippi, R. J., \& Arthur, M. (1994). The boundaryless career: a competency-based career perspective. Journal of Organizational Behavior, 15(4), 307-324.

Elias, P., \& Purcell, K. (2004). A classification of occupations for studying the graduate labour market. Research paper No 6. March 2004. Employment Studies Research Unit: University of West of England and Warwick Institute of Employment Research.

Evans, K., \& Rorris, A. (2010). Optimising the impact of Vietnam's higher education sector on socioeconomic development. In G. Harman, M. Hayden \& Pham Thanh Nghi (Eds.), Reforming higher education in Vietnam; Challenges and priorities (pp. 167-182). London: Springer. 
Fallows, S., \& Steven, C. (2000). Embedding a skills programme for all students. In S. Fallows \& C. Steven (Eds.), Integrating key skills in higher education. London: Kogan Page Limited.

Fatseas, M. (2010). Research-industry cooperation supporting development in Vietnam: the challenge of translating policy into practice. In G. Harman, M. Hayden \& Pham Thanh Nghi (Eds.), Reforming higher education in Vietnam; Challenges and priorities (pp. 103-116). London: Springer.

Flowerdew, J., \& Miller, L. (1995). On the notion of culture in L2 lectures. TESOL Quarterly, 29(2), 345-373.

Fugate, M., Kinicki, A. J., \& Ashforth, B. E. (2004). Employability: A psycho-social construct, its dimensions, and applications. Journal of Vocational Behaviour, 65 (1), 14-38.

General Statistics Office of Vietnam. (2008). The real situation of enterprises. Hanoi.

General Statistics Office of Vietnam. (2012). Higher education statistics. Retrieved 20 August, 2012, from http://www.gso.gov.vn/default.aspx?tabid=395\&idmid=3\&ltemID=11406

George, E. S. (2010). Higher education in Vietnam 1986-1998: Education in transition to a new era? . In G. Harman, M. Hayden \& Pham Thanh Nghi (Eds.), Reforming higher education in Vietnam; Challenges and priorities (pp. 31-50). London: Springer.

Hall, D. T. (1996). Protean careers in the 21st century. Academy of Management Executive, 10 (4), 8-16.

Handy, C. B. (1994). The empty raincoat: Making sense of the future. London: Hutchinson.

Harman, G., Hayden, M. \& Pham T. N. (2010). Higher education in Vietnam: Reform, challenges and priority. . In G. Harman, M. Hayden \& Pham Thanh Nghi (Eds.), Reforming higher education in Vietnam; Challenges and priorities (pp. 1-13). London: Springer.

Harman, G., \& Nguyen T.B.N.(2010). The research role's of Vietnam's universities. In G. Harman, M. Hayden \& Pham Thanh Nghi (Eds.), Reforming higher education in Vietnam: Challenges and priorities (pp. 87-102). London: Springer.

Harman, K., \& Nguyen T.N. B. (2010). Reforming teaching and learning in Vietnam's higher education system. In G. Harman, M. Hayden \& Pham Thanh Nghi (Eds.), Reforming higher education in Vietnam: Challenges and priorities (pp. 65-86). London: Springer.

Harvey, L. (2000). New realities: The relationship between higher education and employment. Tertiary Education and Management, 6(1), 3-17.

Harvey, L. (2005). Embedding and integrating employability. New Directions for Institutional Research, 2005(128), 13-28.

Hayden, M., \& Lam Q. T. (2010). Vietnam's higher education system. In G. Harman, M. Hayden \& Pham Thanh Nghi (Eds.), Reforming higher education in Vietnam: Challenges and priorities (pp. 15-30). London: Springer.

Hillage, J., \& Pollard, E. (1998). Employability: Developing a framework for policy analysis. London: Department for Education and Employment.

Hind, P. (2005). Making room for career change. Career Development International, 10(4), 268-274.

Hoang T. (2009). Educational crisis: Reasons and solutions in globalization challenges. Ho Chi Minh city: Centre for International Education, Culture Exchange and Research.

Holland, S. (2006). Synthesis: A lifelong learning framework for graduate attributes. In P. Hager \& S. Holland (Eds.), Graduate attributes, learning and employability. Dordrecht, The Netherlands: Springer.

Junghagen, S. (2005). Working with business and industry to enhance curriculum development and student employability. New Directions for Institutional Research, 2005 (128), 69-81. 
Knight, P., \& Yorke, M. (2004). Learning, curriculum and employability in higher education. London: Routledge Falmer.

Mallon, M. (1998). The portfolio career: pushed or pulled to it? Personnel Review, 27(5), 361-377.

Mason, G., William, G., \& Cranmer, S. (2009). Employability skills initiatives in higher education: what effects do they have on graduate labour market outcomes? Education Economics, 17(1), 130.

McKnight, A. (1999). Graduate employability and performance indicators: First destinations and beyond. In P. Elias, A. McKnight, K. Purcell \& J. Pitcher (Eds.), Moving On: graduate careers three years after graduation (pp. 24-50). Manchester: Careers Services Unit.

McQuaid, R. W. (2006). Job search success and employability in local labor markets. The Annals of Regional Science, 40, 407-421.

McQuaid, R. W., \& Lindsay, C. (2005). The concept of employability. Urban Studies, 42 (2), 197-219.

Ministry of Education and Training (MOET). (1995). Vietnam education and training directory. Hanoi: Education Publisher.

Mirvis, P. M., \& Hall, D. T. (1996). New organizational forms and the new career. In Hall, D. T. (Ed.), The career is dead - Long live the career (pp. 72-101). San Francisco: Jossey-Bass.

Morley, L. (2001). Producing new workers: Quality, equality and employability in higher education. Quality in Higher Education, 7(2), 131-138.

Nguyen L. (2006). Vietnam's education in the transitional period. Paper presented at the 28th Human Resources Development Working Group Meeting.

Nguyen M. H. (2005). Renovation in higher education in Vietnam - Integration and challenge. Hanoi: Ministry of Education and Training (MOET).

Nguyen P-M, Terlouw, C., \& Pilot, A. (2005). Cooperative learning vs Confucian Heritage Culture's collectivism: Confrontation to reveal some cultural conflicts and mismatch. Asia Europe Journal, 3(3), 403-419.

Nguyen T. N. (2007, 3 Dec. 2007). Strategic choices for Vietnam's higher education. Paper presented at the Strategic Choices for Higher Education Reform, Kuala Lumpur, Malaysia.

Nguyen T. H. (2002). Vietnam: Cultural background for ESL/EFL teachers. Review of Vietnamese Studies, 2(1), 1-6

O'Dwyer, S. (2006). The English teacher: a facilitator and authority. The Electronic Journal for English as a Second Language (TESL-EJ), 9(4), 1-15.

Peiperl, M., \& Baruch, Y. (1997). Back to square zero: the post-corporate career. Organizational Dynamics, 25 (4) (7-22).

Pham L. H, \& Fry, G. W. (2004). Education and economic, political, and social change in Vietnam. Educational Research for Policy and Practice 3(3), 199-222.

Pham M. H. (1998). Vietnam's education: The current position and future prospects. Hanoi: The Gioi Publisher.

Pham T. N. (2010). The higher education agenda: A vision for 2020. In G. Harman, M. Hayden \& Pham Thanh Nghi (Eds.), Reforming higher education in Vietnam: Challenges and priorities(pp. 51-64). London: Springer.

Pham T. H. (2008). Higher education in Vietnam: A look from labour market angle. Hanoi: Vietnam Development Forum.

Phan L. H. (2008). Teaching english as an international language: Identity, resistance and negotiation. Clevedon, UK: Multilingual Matters Ltd.

Pool, L. D., \& Sewell, P. (2007). The key to employability: developing a practical model of graduate employability. Education and Training, 49(4), 277-289. 
Rae, D. (2004). Practical theories from entrepreneurs' stories: discursive approaches to entrepreneurial learning. Journal of Small Business and Enterprise Development, 11(2), 195202.

Rae, D. (2007). Connecting enterprise and graduate employability. Education and Training, 49(8/9), 605-619.

Sanders, J., \& de Grip, A. (2004). Training, task flexibility and the employability of low-skilled workers. International Journal of Manpower, 25(1), 73-89.

Shah, A., Pell, K., \& Brooks, P. (2004). Beyond first destinations. Active learning in higher education, 5(1), 9-26.

Smith, J., Knight, A., \& Naylor, R. (2000). Graduate employability: Policy and performance in Higher Education in the UK. Economic Journal 110(464), 382-411.

Smith, L., \& Nguyen Q. D. (2010). Processes for Strategic Planning in Vietnam's Higher Education System. In G. Harman, M. Hayden \& Pham Thanh Nghi (Eds.), Reforming higher education in Vietnam: Challenges and prioirities. (pp. 143-154). London: Springer.

Stephen, W., Doughty, P., Gray, P. J., Hopcroft, J. E., \& Silvera, I. F. (2006). Observations on undergraduade education in computer science, electrical engineering, and physics at select universities in Vietnam. Washington: Vietnam Education Foundation.

Ta T. A., \& Winter, R. (2010). Processes of modernization in two public universities in Vietnam: University managers' perspectives. In G. Harman, M. Hayden \& Pham Thanh Nghi (Eds.), Reforming higher education in Vietnam: Challenges and priorities. (pp. 155-166). London: Springer.

The Association of Graduate Recruiters. (2009). Skills for graduates in the 21st century. Retrieved 12 April 2010, from http://www.funkygrad.com/ratedserious/displayarticle.php?artID=202\&subcat=career

Thompson, J. (2009). Changing chalk and talk: The reform of teaching methods in Vietnamese higher education. Unpublished independent study project paper. Washington D.C.: The George Washington University.

Tomlinson, M. (2008). 'The degree is not enough': students' perceptions of the role of higher education credentials for graduate work and employability. British Journal of Sociology of Education, 29(1), 49-61.

Tran H. (1999). Vietnamese higher education: In search of an identity. International Higher Education, 15(3), 20-22.

Tran N. C. (2006). Universities as drivers of the urban economies in Asia: The case of Vietnam. Policy Research Working Paper: Washington, D.C.: World Bank.

Tran Q. T, \& Swierczek, F. W. (2009). Skills development in higher education in Vietnam. Asia Pacific Business Review, 15(4), 565-586.

Tran T. T. (2010a). Decentralization in higher education in Vietnam: Some practical issues. Paper presented at the Decentralization in Higher Education from a Global Perspective: Implication for Vietnam and the Region, Ho Chi Minh city, Vietnam.

Tran T. T. (2010b). Enhancing graduate employability: Challenges facing higher education in Vietnam. Paper presented at the The 14th UNESCO-APEID International Conference: Education for Human Resource Development, Bangkok, Thailand.

Tran T. T. (2010c). Enhancing graduate employability: International context versus Vietnamese context. Paper presented at the 4th International Graduate Conference in Social Sciences and Management, Bradford, UK.

Tran T. T. (2012). Is the learning approach of students from the Confucian heritage culture problematic? Education Research for Policy and Practice. DOI 10.1007/s10671-012-9131-3. 
Tran T.T., \& White, J. (2012). Managed universities: Vietnam and the West. In M. Vicars, T. McKenna \& J. White (Eds.), Discourse, power and resistance down under. (pp. 151-160). Rotterdam: Sense.

Van Buren III, H. J. (2003). Boundaryless careers and employability obligations. Business Ethics Quarterly, 13(2), 131-149.

Vu N.H. (2009). Recognising challenges, opportunities and requirements for Vietnam education in globalizing era (Nhận diện thách thức, cơ hội, và yêu cầu đối với giáo dục Việt nam trong bối cảnh toàn cầu hóa). Paper presented at the Comparative Education Conference, Ho Chi Minh city.

Vu N.H., Dang B. L., \& Tran K. D. (2007). Vietnam education: Renovation and development (Giáo Dục Việt Nam: Đổi mới và Phát triển Hiện đại hóa). Ho Chi Minh city: Giao Duc publication.

Vu Q.V. (2008). Vietnamese education: Downgrade causes and the necesary renovations (Giáo Dục Việt Nam: Nguyên nhân của sự xuống cấp và các cải cách cần thiết). Thoi Dai Moi, 13(3), 18.

Yorke, M. (2006). Employability in higher education: What it is - What it is not (Vol. 1). York: The Higher Education Academy.

Yorke, M., \& Knight, P. (2004). Embedding employability into the curriculum. York: Higher Education Academy.

\section{Legislation}

The Education Law, Law number 38/2005/QH11 (2005). (The National Assembly of the Socialist Republic of Vietnam, Legislature XI, Hanoi). Retrieved from:

http://en.moet.gov.vn/?page $=8.8 \&$ view $=5101$ 